\title{
Prevalence and pathological study of schistosomiasis in sheep in Akra/Dohuk province, northern Iraq
}

\author{
I.K. Zangana ${ }^{1}$ and K.J. Aziz ${ }^{2}$ \\ ${ }^{1}$ Department of Clinical Science, College of Veterinary Medicine, Dohuk University, \\ ${ }^{2}$ Department of Animal Resources, College of Agriculture, Salahaddin University, Iraq
}

\begin{abstract}
The occurrence of Schistosomiasis was detected by fecal examination (Formalin- ether centrifugalsedimentation technique) and abattoir Survey during a period from October 2006 to March 2007,andhistopathological study. Schistosomabovis was identified with prevalence rate $11.37 \%$ by fecal examination where as $1.6 \%$ by abattoir survey. Diseased animals exhibited acute clinical signs, which included emaciation, sunken eye, pale mucus membrane and diarrhea. The Infections was more prevalent in age 1-3 years 15.9\%. The histopathological findings reveal characteristic lesions in blood vessels and some tissues including thrombosis in veinuoles and mesenteric vein and minute granuloma around the eggs in portal area and fatty necrosis in the liver, cystic structure of some mucosal glandsof the intestine containing eggs, with infiltration of mononuclear inflammatory cells in different tissues.
\end{abstract}

Keywords: Schistosomiasis; Sheep; Prevalence.

Available online at http://www.vetmedmosul.org/ijvs

$$
\begin{aligned}
& \text { نسبة حدوثية ودراسة مرضية لمرض البلهارزيا في الاغنام }
\end{aligned}
$$

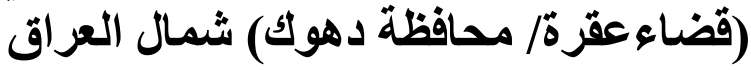

$$
\begin{aligned}
& \text { احسان قادر زنكنة' وخالا جبار عزيز ' } \\
& \text { 'فرع الطب الباطني، كلية الطب البيطري، جامعة دهوك، كَقسم الثروة الحيوانية، كلية الزر اعة، جامعة صلاح الدين، اربيل، العراق } \\
& \text { الخلاصة }
\end{aligned}
$$

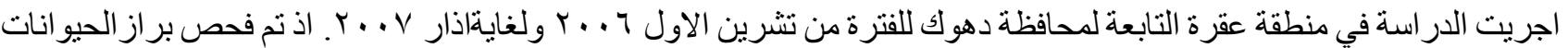

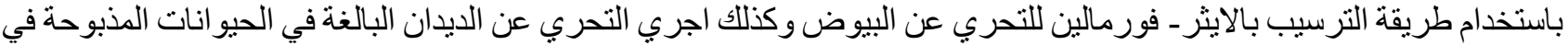

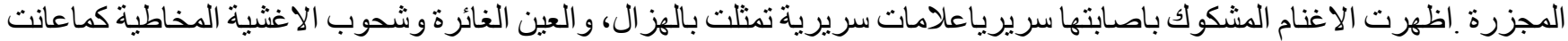

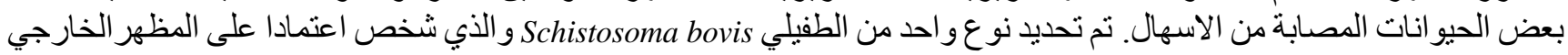

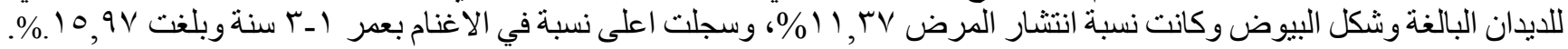

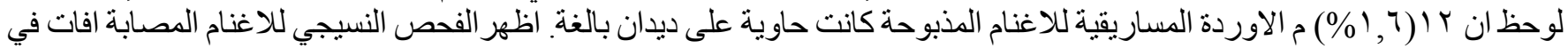

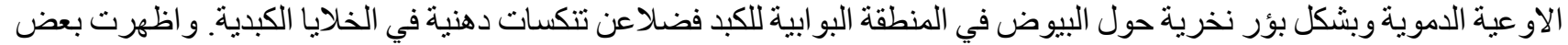

$$
\begin{aligned}
& \text { الغددالمخاطية للامعاء وجود توسعات كيسية حاوية على البيوض مع ارنتشاح للخلايا وحيدة النواة مابين تللك الغدد. }
\end{aligned}
$$

\section{Introduction}

Schistomiasis is a common parasitic infection in animal,mainly incattle in Africa and Asia, its estimated that at least 165 million animals infected (1). Out of 10 species reported to naturally infect cattle only,Schistosomamattheei and $S$. bovis have received particular attention, mainly because of their recognized veterinary significance (2).
Schistosomabovis is a species' whose final hosts are bovines,ovines, caprines and whose secondary hosts are small wild ruminants they are distributed throughout Africa, south west Asia and Mediterranean, Europe.Different studies have demonstrated the analogies existing between $S$. bovis and other Schistosoma species which affect humans. The similarities include 
morphological, ecological, physiological and genetic aspects (3-5).

In Iraq the infections with $S$. bovis at the first time is recorded by (6) in cattle, sheep, goat and equine. Also a survey was carried out on a parasitic infection among animals indifferent provinces of Iraq by (7). The S. bovis was found in cattle, sheep, goats and the intermediate hosts were found to be respectively, Bulinustrancatus and limnaeaeuphratica, while (8) recorded two types of Bilharzias in Iraq (S. bovis, Orinthobilhazriaturkestanicum).

There are considerably fewer publications on ovine Schistosomiasis in Iraq and also due to two outbreaks of the disease recently occurred during 2004-2005 among the sheep in one district (Akra) Duhok province North of Iraq. These two reasons encouraged to plan this study.

\section{Materials and methods}

\section{Epidemiological Data}

The study was conducted in Akra (a district located $90 \mathrm{~km}$ north east of Mosul province). Sheep (90\% Karadi breeds) at this area graze on the natural pasture near the several rainfall pools, drains, rice field and temporary streams which distributed in this area.

Full objective information obtained which was arranged in a sheet of questionnaire form including data of sex, age, flock, size, morbidity and mortality rates.

\section{Sampling}

\section{Field samples}

A total of 290 fecal samples were taken from 32 flocks of sheep in 16 different villages from October 2006- March 2007.Samples were kept in a clean dry container without contamination for one or more days at refrigeration, until examination.

\section{Abattoir samples}

A total of 1130 mesenteric vessel of sheep were examination thoroughly by visual inspection, by holding the mesentery for the detection of adult parasite to the light and were readily recognized black streak of digested blood in their gut of adult worm Fig.1.

The adult worm was collected from mesenteric vein and washed several times by normal saline and preserved in ethanol $70 \%$ for morphological description. Also samples from organs (Liver, mesenteric vessels, intestine, Lung and lymph nodes) were taken from those infected animals (In depending on the observation of adult worm in mesenteric veins) and fixed in $10 \%$ saline formalin for histopathological study (9) histotechnique was applied for histological examination.

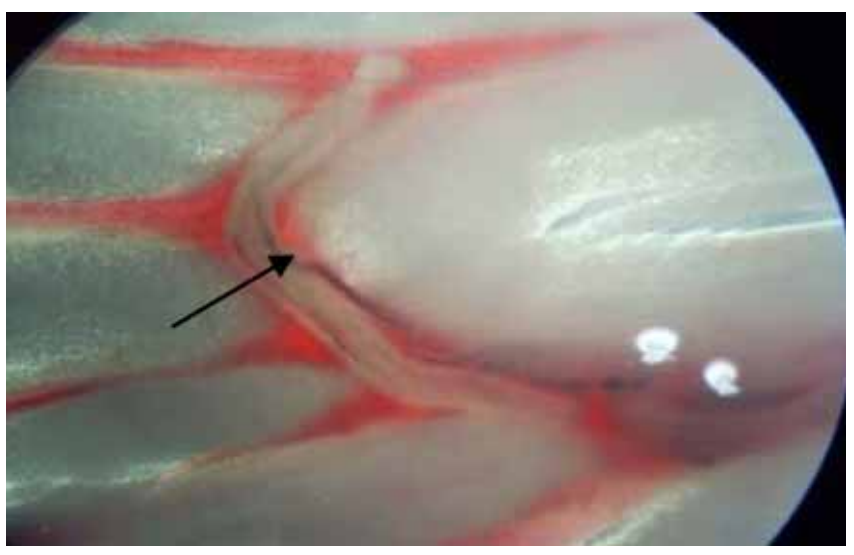

Figure (1): Mesenteric vein contain adult worm of S. bovis $(\uparrow)$, black streak of digested blood in their gut.

\section{Coprological examination}

Sedimentation test: (Formalin-ether centrifugal sedimentation)Formalin-ether technique was used for effective concentrating eggs in feces as method described by (10). The shape and size of egg was determined by using ocular micrometer lens applying method of (11).

\section{Results}

\section{Clinical findings}

Diseased animals showunthriftness, loss of conditions, anorexia, intermittent diarrhea, mixed with blood, dehydration, sunken eyes, more over severe emaciation and thirst were also encountered. systemic reactions was mild however pale mucous membrane, polypnea and nasal discharge were also seen.

\section{Parasitological findings}

The morphological feature of isolated adult worm was

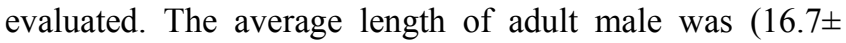
$1.3 \mathrm{~mm}$ ) and it had two suckers (oral and ventral) and distinct gynacophoric canal and 3-6 testicles situated behind the ventral sucker, and in all specimens showed male holding the threadlike female in gynacophoric canal Fig.2. The egg was elongated spindle shaped with large terminal spine. The average size of the eggs was $266 \pm 11.6 \mu \mathrm{m}$ length and $58 \pm 3.7 \mu \mathrm{m}$ width Fig.3.

\section{Abattoir findings}

Result of abattoir survey show that out of 1130 mesenteric vein examined $12(1.06 \%)$ were appeared infected with adult worms (Table 1). The rate of infection was taken similarity among the periods of survey as shown in table (4). The rate was $(0.52 \%),(1.05 \%),(1.94 \%)$, $(1.53 \%),(1.07)$ in October, November, December, January and February, respectively, however no worm were detected in March 2007. 
Table (1): Prevalence rate of Schistosomabovis in sheep.

\begin{tabular}{lcccc}
\hline Type of exam. & Type of sample & No. sample exam. & No. sample positive & Percentage \% \\
\hline Microscopically exam. & Feces & 290 & 33 & 11.37 \\
Visual inspection. & Mesenteric vessels & 1130 & 12 & 1.06 \\
\hline
\end{tabular}

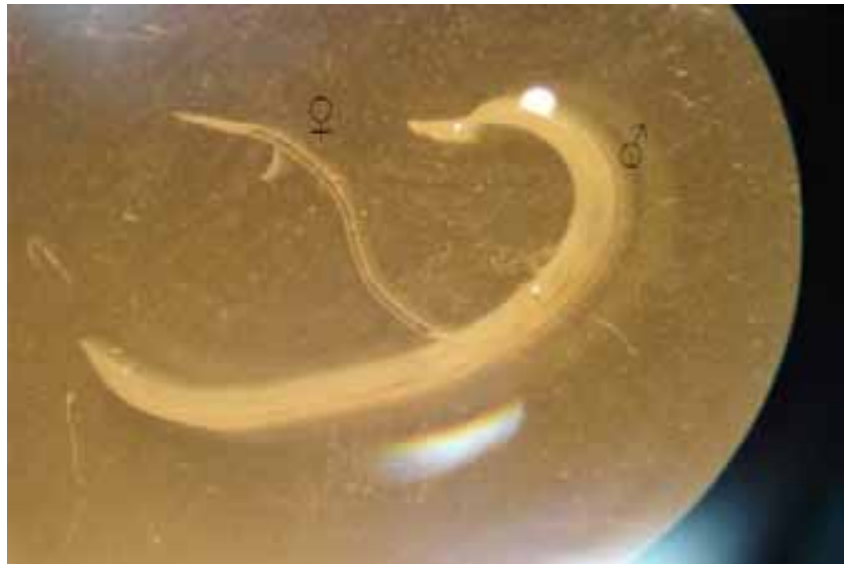

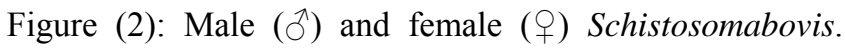
$40 \mathrm{X}$ dissecting microscope.

\section{Field finding:}

Out of 290 fecal samples of suspected sheep 33 $(11.37 \%)$ were passed feces with typical eggs which were detected microscopically(Table 1$)$. Highest rate $(27.45 \%)$ was detected on January 2006 where as the lowest $(9.75 \%)$ in November 2006, moreover no infection rate have been recorded in October 2006 and March 2007 (Table2). According to the age of animals, results show that animals aged 1-3 year were highly infected (15.97\%) whereas animals aged above 3 years have low infection rate $(10.75 \%)$. Moreover no infection have been recorded in young animals under one year old. (Table3).

Table (2): Prevalence rate of Schistosomabovis from fecal sample in sheep related to different months.

\begin{tabular}{lccc}
\hline Months & $\begin{array}{c}\text { No. of } \\
\text { samples }\end{array}$ & $\begin{array}{c}\text { No. of + ve } \\
\text { samples }\end{array}$ & $\begin{array}{c}\text { Percentage } \\
\text { of positive } \\
\text { sample (\%) }\end{array}$ \\
\hline October 2006 & 52 & 0 & 0 \\
November 2006 & 41 & 4 & 9.75 \\
December 2006 & 56 & 6 & 10.71 \\
January 2007 & 51 & 14 & 27.45 \\
February 2007 & 48 & 9 & 18.75 \\
March 2007 & 42 & 0 & 0 \\
\hline Total & 290 & 33 & 11.37 \\
\hline
\end{tabular}

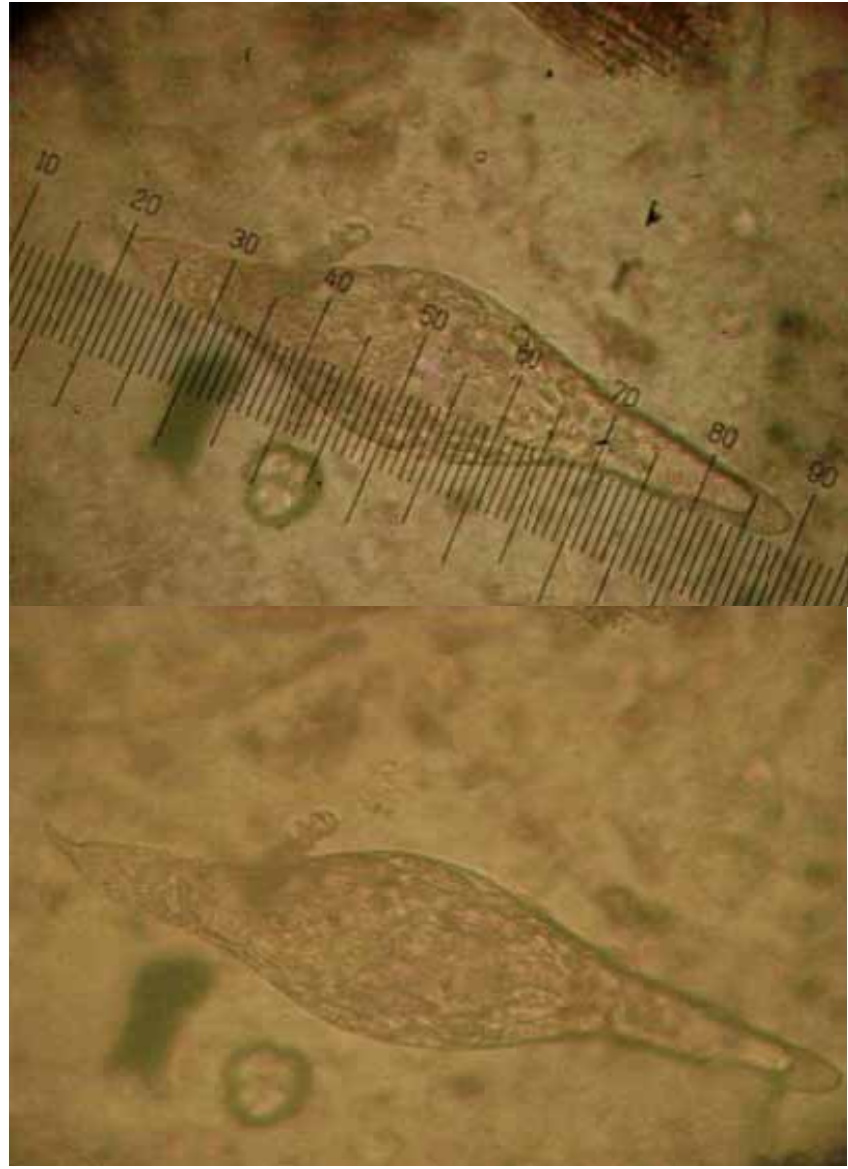

Figure (3): The egg of S.bovis; spindle, elongated shape containing fully developed miracidium, and showing long terminal spine.

Table (3): Prevalence of Schistosomabovis infection according ages in sheep.

\begin{tabular}{lccc}
\hline Age Groups & $\begin{array}{c}\text { No. of } \\
\text { animal } \\
\text { examined }\end{array}$ & $\begin{array}{c}\text { No. } \\
\text { Infected } \\
\text { animal }\end{array}$ & $\begin{array}{c}\text { Infection } \\
\%\end{array}$ \\
\hline Under 1Year & 53 & 0 & 0 \\
$1-3$ & 144 & 23 & 15.97 \\
Above 3 years & 93 & 10 & 10,75 \\
\hline Total & 290 & 33 & 11.37 \\
\hline
\end{tabular}


Table (4):Prevalence rate of S.bovis from Akra abattoir in sheep related to different months.

\begin{tabular}{lccc}
\hline Months & $\begin{array}{c}\text { No. of } \\
\text { samples }\end{array}$ & $\begin{array}{c}\text { No. of + ve } \\
\text { samples }\end{array}$ & $\begin{array}{c}\text { Percentage } \\
\text { of positive } \\
\text { sample (\%) }\end{array}$ \\
\hline October 2006 & 172 & 1 & 0.58 \\
November 2006 & 189 & 2 & 1.05 \\
December 2006 & 206 & 4 & 1.94 \\
January 2007 & 196 & 3 & 1.53 \\
February 2007 & 186 & 2 & 1.07 \\
March 2007 & 181 & 0 & 0 \\
\hline Total & 1130 & 12 & 1.06 \\
\hline
\end{tabular}

\section{Histopathologicalfindings}

Liver

Hepatic tissue sections showed fibrosis in portal area and associated with congestion and coagulative necrosis in surrounded portal area, moreover vascular degeneration and fatty change had been seen in hepatocytes. Fig4.

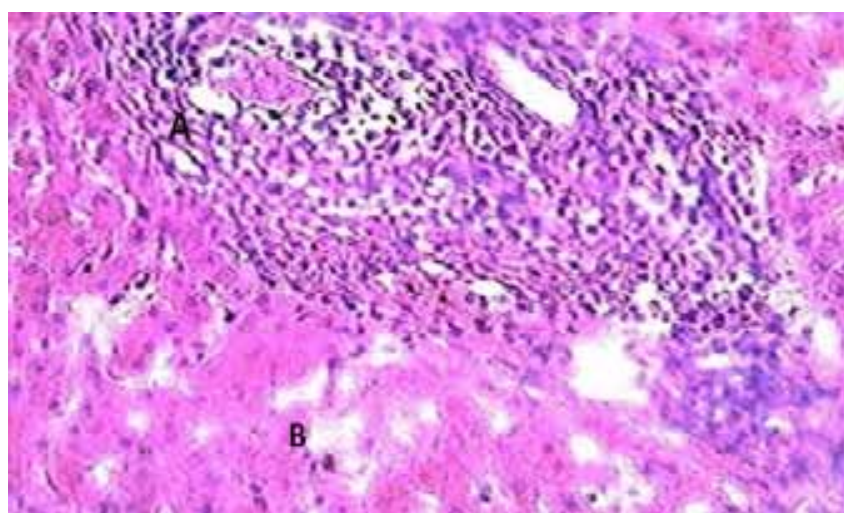

Figure (4): Histological section of liver from infected sheep revealed fibrosis infiltrated with mononuclear inflammatory cells around the egg of Schistosomabovisin portal area (A), associated with fatty change (B). H and E 400x.

\section{Intestine}

The infected intestine revealed sever necrosis in mucosa and sub mucosa, and degeneration of epithelial villi and hyperplasialining of sub mucosal glands, some of which changed into the compact mass, while others changed into cystic structure containing eggs of parasite. Fig. 5.

\section{Mesentery and mesenteric vein}

The histopathological change of mesentery arterioles and veiniols revealed sever congestion and thrombophelibitis and deposition of the eggs with filtration of mononuclear cells and fatty necrosis Fig.6 and 7. However thickening in the wall of arterioles, presence of parasite in lumen of vein, inflammatory cells mixed with deposition of eggs and cross section of adult parasite in lumen of vein have been also detected. Fig. 8.

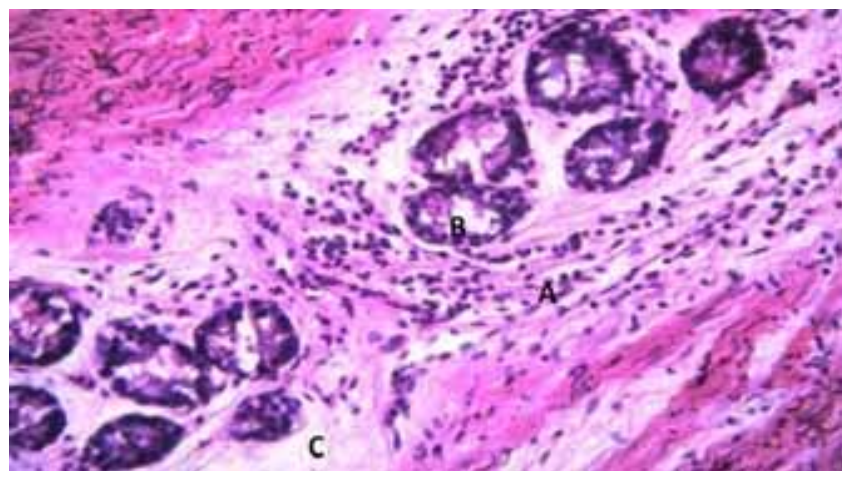

Figure (5): Histological section from intestine of sheep revealed fibrous tissue infiltrated by mononuclear inflammatory cells surrounded mucosal gland (A), hyperplasia in epithelial lining mucosal gland (B), atrophied compact gland (C). H and E 400x.

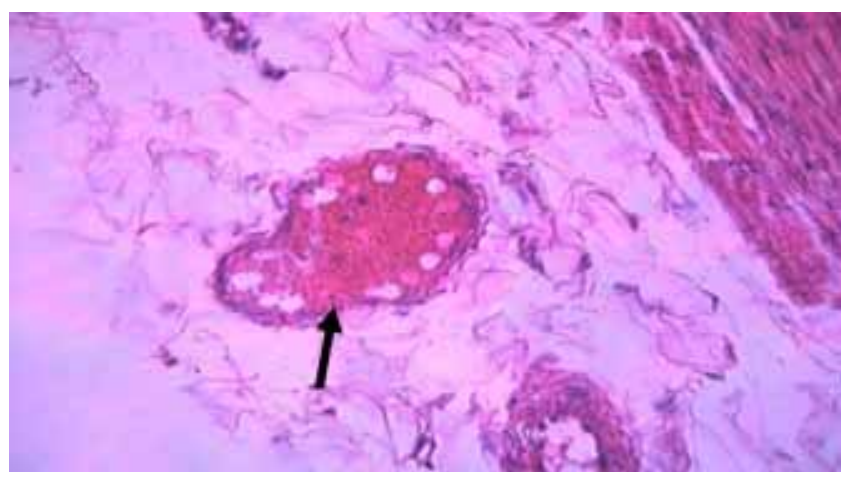

Figure (6): Histological section of mesentery revealed presence of thrombus in veinuole $(\uparrow) . \mathrm{H}$ and $\mathrm{E} 400 \mathrm{x}$.

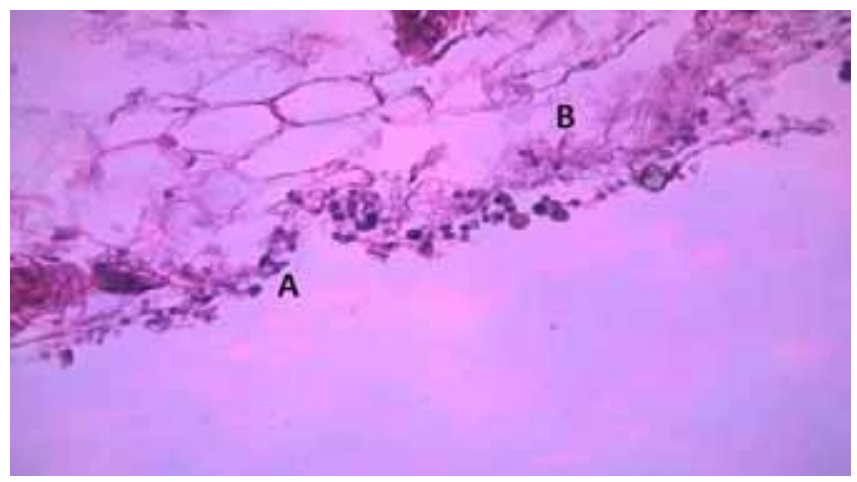

Figure (7):Histological section from mesentery of sheeprevealed presence ofSchistosoma egg associated with infiltration of mononuclear inflammatory cells (A) and fatty necrosis (B).H and E 400x. 


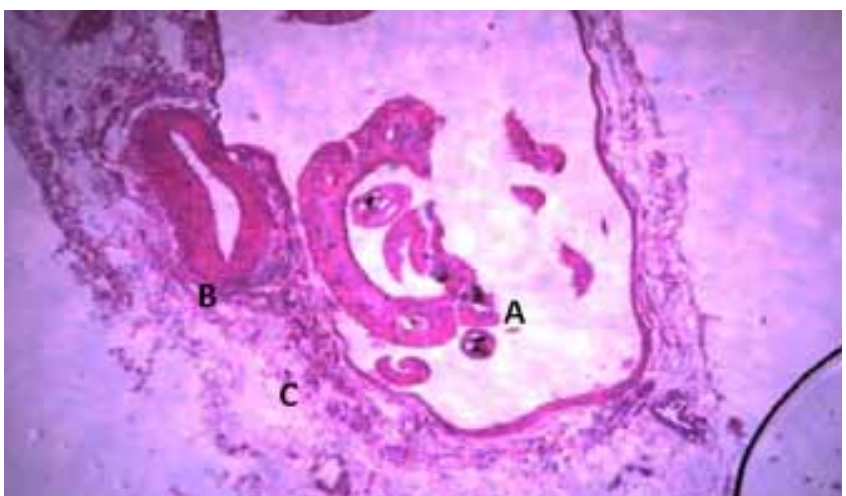

Figure (8): Histological section from mesenteric vein revealed cross section of parasite (A), thickening in wall of arterioles (B), infiltration of inflammatory cells around the wall (phlebitis) (C). $\mathrm{H}$ and $\mathrm{E} 400 \mathrm{x}$.

\section{Lung}

There was emphysema with bronchopneumonia, severe congestion in pulmonary arteries and hyperplasia in the epithelial lining of bronchioles. Fig. 9.

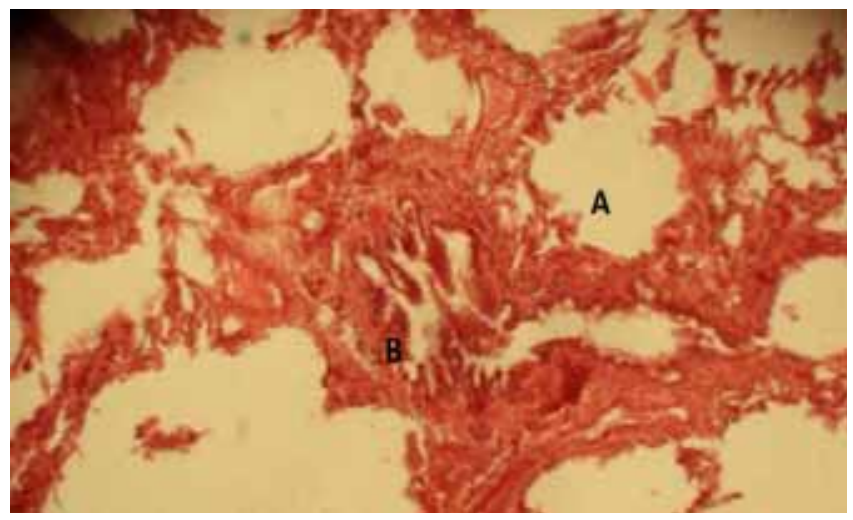

Figure (9): High magnification of above figure revealed some pathological lesions represented by emphysema (A) and severe congestion, in pulmonary arteries and hyperplasia in epithelial lining of bronchioles (B). $\mathrm{H}$ and $\mathrm{E}$ 400x.

\section{Lymph nodes}

There was depletion in some secondary lymph node follicle, periarteritis and infiltration of mononuclear inflammatorycell (monocyte) in medulla of the lymph node. Fig.10.

\section{Discussion}

During last two years (2005-2006) outbreaks of Schistosomiasis in sheep occurred in the region of Akra, Duhok province, north of Iraq. At this area the distribution and ultimation of aquatic snails had been propagated the different flukes infection among live stock. Studies of Schistosomiasis in Iraqi animals are very scarce and little information have been provided, there forthe present study was carried on this disease more epizootically dealt, the study depend on fecal examination, abattoir survey and on basis of morphology of adult parasite and eggs, similar steps were followed by many authors (12-14).

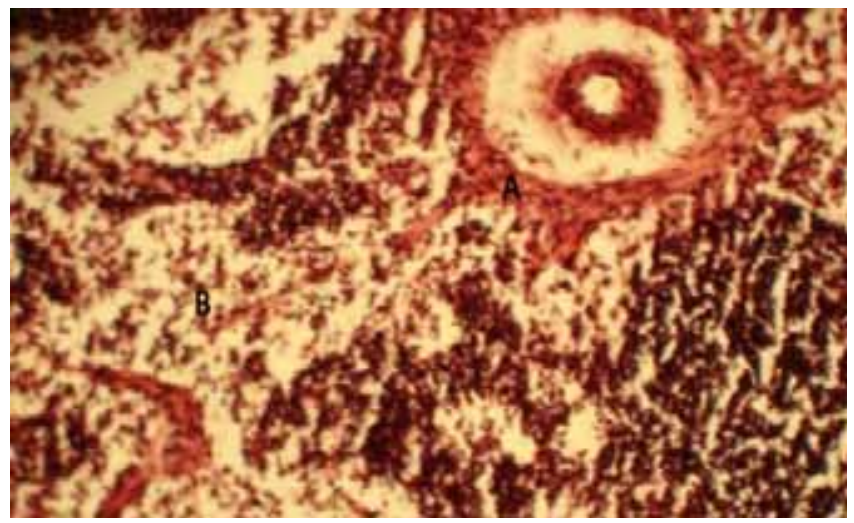

Figure (10): High magnification of above figure revealed periarteritis (A) and infiltration of mononuclear inflammatory cell (monocyte) in medulla (B). $\mathrm{H}$ and $\mathrm{E}$ 400x.

Accordinglydetection ofS.bovis was proved the cause of Schistosomainfection in this region this species reported by Lepier in 1975 from different province of Iraq. The parasite were also observed by (15) from mesenteric vein of cattle in slaughter house of Dyala province at rate of $0.94 \%$.

Results indicated that the infection rate was high in January and low in November, this variability in rate may be due to amount of rainfall, ambienttemperature and drought condition which depended on establishing of water reservoir for propagation of snails which were intermediate hosts.

High infection rate which were detected in animals of 13 year old were agreed with (16) whom registered high infection with Schistosomiasis in enzootic area of central Sudan.

Acute Schistosomiasis found in this study, this signs due to high morbidity and mortality and severity of condition depend on the distribution of mature worms and on egg deposited in tissues. Some explanation of acute occurrence of acute infection had been given by (17).

Through the histological finding in different organs proved the acuteness of infection, the basic lesion was phlebitis due to the death of adult parasite, loading in blood vessels in the liver, lung and intestine these changeswere recorded by (18), whom mention that sever infection causes consolidation and fibrosis of liver with the presence of 
massive thrombosis in the portal vessels and local infiltration of multi nucleated in the liver parenchyma and around the portal veins in addition the large numbers of worms in visceral and portal veins caused phlebitis and the presence of eggs in the intestine causes inflammatory response.

The mesenteric vein revealed thickening in the wall of arteriole and adult parasite in the lumen of vein and infiltration of inflammatory cells mixed with deposition of eggs, these also were mentioned by (19).

\section{References}

1. De Bont J, Vercruysse J. The epidemiology and control of cattle schistosomiasis.Parasitol Today. 1997; 13:255-262.

2. Taylor M G. Schistosomes of domestic animals: Schistosomabovisand other animal forms. In immunology, Immunoprophylaxis and immunotherapy of parasitic infection.Ed Soulsby EJL. Boca Raton, Florida: CRC Press. 1987; 2: 49-90.

3. Camacho M, Agnew A. Glucose uptake rate by Schistosomamansoni, S. haematobiumand S.bovis adults usingaflow in vitro culture system. J. Parasitol. 1995;81:637-640.

4. Barber K E, Mkoji G M and Loker E S. PCR-RFLP analysis of the ITS2 region to identify Schistosomahaematobium and S,bovis from Kenya. Am. J. Trop. Med. Hyg. 2000;62:434-440.

5. Hamburger J, He-Na I, Abbasi R M, Ramzy J,Jourdane, and RuppelA.Polymerase chain reaction assay based on a highly repeated sequence of Schistosomahaematobium: a potential tool for monitoring schistosome infested water. Am. J. Trop. Med. Hyg. 2001; 65:907911.

6. Machattie C. (1936) The relation between Schistosomiasis (Bilharziasis) in domestic animals and man as observed in Iraq. Ph.D.
Thesis submitted to veterinary faculty, university of Zurich. Cited by AL-Biaty (2000).

7. Leiper R T. Report on theIV. Survey of parasites and their control. FAO, (1957);/ 57/3/1673:4-23.

8. Al- Barrak N S, Wajdi N and Fadhil S. Observation on Schistosomes parasitic in cattle in Iraq. Iraq. J.Biol. Sci., 1977; 5(1):69-80.

9. Bancroft J D, Stevens A. Theory and practice of Histological Techniques. $4^{\text {th }}$ Ed. Churchill Livingstone. 1999; 127-129.

10. Lynne S G A B,Lawrence R A. Diagnostic parasitology, parasite identification. $2^{\text {nd }}$ Ed.The C.V.Mosby co; Missauri, U.S.A. 1979.

11. Pantin C F A. Notes on Microscopical Techniques for Zoologists. $6^{\text {th }}$ Ed.Cambrige Uni. Press.1964; Pp: 77.

12. Hamilton $\mathrm{J} \mathrm{V}, \mathrm{K}$ linkert Mand Doenhoff $\mathrm{M}$ J.Diagnosis of Schistosomiasis: anti body detection, with notes on parasitological and antigen detection method. Parasitol.1998; 117(suppl):s41-s45.

13. Allen G P, Adrian C S, Richard O G, Gail M Wand Donald P M. Schistosomiasis. The New England Journal of Medicine. 2002; Vol.346, No.16 :1212-1220.

14. Corachan M. Schistosomiasis and international travel. Clin.infect. Dis. 2002;35:446-450.

15. AL-Biaty S H. Epidemiological study of Schistosomahaematobium in Baladrooze sub province. M.sc. thesis submitted to the council of the college of veterinary medicine at the University of Baghdad,2000.

16. Majid A A,Hussein M F and Taylor M G. Age specific prevalence and intensity of Schistosomabovis infection in Sudanese Desert sheep in the White Nile Province. Res Vet Sci.1983; 35(1):120-1.

17. Dargie J D. The pathogenesis of S.bovis infection in Sudanese cattle. Trans. R, Soc. Trop. Med. Hyg. 1980;74: 560-562.

18. Lindberg R, Johansen $M V$, Nitsson $C$ and Nansen $P$. An immunohistological study of phenotypic characteristics of cells of the inflammatory response in the intestine of Schistosomabovis infected. Parasitol. 1998;118: 91-99.

19. Jones T C, Hunt R D and King N W. Veterinary Pathology. $6^{\text {th }}$ Edition. Lippincott Williams and Wilkins A Wolters Kluwer Company.London. 1997; 664-667. 